\title{
The Influence of Arbuscular Mycorrhizal Fungi Inoculation on Micro-Propagated Hybrid Yam (Dioscorea spp.) Growth and Root Knot Nematode (Meloidogyne spp.) Suppression
}

\author{
Atti Tchabi ${ }^{1 *}$, Fabien C.C. Hountondji ${ }^{2}$, Bisola Ogunsola ${ }^{3}$, Louis Lawouin ${ }^{4}$, \\ Danny Coyne ${ }^{4}$, Andres Wiemken ${ }^{5}$ and Fritz Oehl ${ }^{6}$ \\ ${ }^{1}$ Université de Lomé, Ecole Supérieure d'Agronomie, Département de la \\ Défense des Cultures, BP 1515 Lomé, Togo \\ ${ }^{2}$ Université des Sciences, Arts et Techniques de Natitingou,Ecole Nationale Supérieure des \\ Sciences et techniques Agronomiques de Djougou \\ ${ }^{3}$ International Institute of Tropical Agriculture (IITA), Oyo Road, Ibadan, Nigeria \\ ${ }^{4}$ International Institute of Tropical Agriculture (IITA), IITA-Benin, Abomey Calavi \\ ${ }^{5}$ Plant Science Center Zurich-Basel, Institute of Botany, University of Basel, Hebelstrasse 1, \\ CH-4056 Basel, Switzerland \\ ${ }^{6}$ Agroscope Reckenholz-Tänikon Research Station ART, Ecological Farming Systems, \\ Reckenholzstrasse 191, CH-8046 Zürich, Switzerland \\ *Corresponding author
}

Keywords

Bio-control, damage, Meloidogyne spp., greenhousecondition, Yam.

\section{Article Info}

Accepted:

14 September 2016 Available Online: 12 October 2016

\section{A B S T R A C T}

The use of commercial inoculants containing non-indigenous arbuscular mycorrhizal fungi (AMF) is an emerging technology towards improving crop production in Africa. The present study aims at evaluating the influence of two strains of commercial arbuscular mycorrhizal fungi (AMF) products, based on Funneliformis mosseae and Glomus dussii, on yam growth and on root knot nematodes suppression. Using micropropagated plantlets two cultivars each of Dioscorea alata (TDa98-01183 and TDa98-165), and D. rotundata (TDr97-00551 and TDr 745) were inoculated with the $F$. mosseae and $G$. dussii products separately, at transplanting into $2 \mathrm{~L}$ pots, and then inoculated one month later with 500 infective juveniles of Meloidogyne spp. and grown for further seven months in the greenhouse. Results demonstrated that even with low colonization rates (6\%), AMF led to improved yam growth, especially for D. alata. When challenged with Meloidogyne spp., AMF inoculation significantly suppressed galling symptoms across the treatments and led to higher tuber yield. This study indicates the potential of AMF to sustainably improve yam quality and productivity, although further screening should be done in order to identify a suitable combination AMF species/strain $\mathrm{x}$ cultivar compatibility to optimise the results. 


\section{Introduction}

Botanically, yam (Dioscorea spp.) is a monocotyledon plant with more than 600 species in the genus. It is widely cultivated as a tuber crop in West and Central Africa, in Asia and in Central and South America (Ayensu and Coursey, 1972; Okwor, 1998). Globally, yam is the second most important root and tuber crop after cassava, in terms of production and in West and Central Africa production zone, where it is a particularly important staple food crop; its consumption contributes more than 200 calories per day for almost 60 million people (FAO, 2013). In West Africa, yam production is expanding annually but the realized yields are usually considerably lower than potential yields (IITA, 2014). The increasing human population and consequent land pressure result in shortened fallows or more consecutive cropping of land, leading to degradation in soil fertility and an increase in pest and disease levels (Sanchez, 2002). Among the key pests, the plant parasitic nematodes Meloidogyne spp. and Scutellonema bradys are a particular nuisance to productivity, tuber quality, storage and seed viability in West (Adegbite et al., 2005). Meloidogyne spp. so far identified to be associated with yam in West Africa are $M$. arenaria, M. enterolobii, $M$. incognita, M. javanica, and M. hapla of which M. incognita is reported to be the most important (Bridge et al., 2005; Kolombia et al., 2014). Infected tubers become deformed and disfigured, affecting their quality and marketability, but also act to re-infect following crop cycles if infected tubers are used as seed material. The value of galled tubers is estimated to be between $39-52 \%$ lower than healthy ones [9] (Nwauzor and Fawole, 1981). The proportion of galled tubers collected from yam barns and markets in Nigeria can be as high as $90 \%$ for Dioscorea alata and $70 \%$ for $D$. rotundata (Adesiyan and Odihirin,
1978), although in general the proportion of affected yams is much lower on average (Coyne et al., 2006), but appears to be increasing over time during the stored period (Kolombia et al., 2014). Previously, synthetic chemical nematicides have been a primary means of controlling root-knot nematodes on yam (Ayodele and Agbaje, 2007). However, their highly hazardous nature has led to many of these products being removed from the market and their use discontinued] (FAO, 2013). Other nematode management practices on yam tubers, such as hot water treatment (Speijer, 1996; Coyne et al., 2009), organic fertilizers (Agu, 2008; McSorley, 2011; Osei et al., 2013) or cultural control (Claudius-Cole et $a l, 2014)$ have been explored for yam with some success. Screening for resistant cultivars has also been conducted with varying levels if resistance identified (Onyeke and Akueshi, 2012; Ettien et al, 2013; Osei et al, 2015). Recent progress in biotechnology has also shown that in vitro meristem tissue culture of yam can provide disease- and pest-free planting material (IITA, 2006). However, as sterile plantlets free of pathogens, they are also free of their natural protective endophytic microorganisms, which normally reside in planta, often with beneficial impact (Cassells, 2012) such microorganisms may be arbuscular mycorrhizal fungi (AMF). AMF are important elements of the soil microflora in agroecosystems, which form a mutualistic symbiosis with most plant species, including almost all plants currently micropropagated (Smith and Read, 2008). Root colonization by AMF favors plant development by increasing nutrient uptake, hormonal activity, growth rate and consequently yield (Naher et al., 2013; Lone et al., 2016). Previous studies were conducted on the protective effect of AMF root colonization against soil borne pathogens such as nematodes and the 
mechanism involved (e.g. Azcon-Aguilar and Barea, 1997; Borowicz, 2001; Hol and Cook, 2005; Schouteden et al., 2015). Indigenous or introduced AMF have been shown to benefit production of various crops, such as vegetables (Affopkon et al., 2011), cassava (Straker et al., 2010), Sweet potatoes (Halder et al., 2015) and potatoes (Carpio et al., 2005; Farmer et al., 2006; Wu et al., 2013) to name a few. On yam a number of studies have demonstrated the high mycorrhization of the crop with a range of AMF species and the apparent high level of association under natural conditions (Tchabi et al 2009), including the efficiency of AMF colonization on yam growth and yield (Oyetunji and Afolayan, 2007; Tchabi et al., 2010; Lu et al. 2015).

Furthermore, few studies regarding the effect of AMF on yam nematodes have shown the suppressions of Scutellonema bardys (Tchabi, 2008) in the greenhouse conditions. Moreover there is no report regarding a tripartite interaction including AMF, Meloidogyne spp. and yam plants. The present study evaluates the effect of two commercially available AMF products, based on Funneliformis mosseae and Glomus dussii, on infection of yam by Meloidogyne spp.

\section{Materials and Methods}

\section{Experimental site}

The experiment was conducted in 2 litre pots in the greenhouse at the IITA-station, Cotonou, Benin, situated between $6^{\circ} 25.256 \mathrm{~N}$ and $2^{\circ} 19.719 \mathrm{E}$, at an altitude of $23 \mathrm{~m}$ asl. The site is characterized by subequatorial climate with two rainy seasons from March to July and from September to November and two dry seasons in between. The ambient temperature varies between 29 $34^{\circ} \mathrm{C}$ during the day, $24-27^{\circ} \mathrm{C}$ during the night and the relative humidity between $70 \%$ and $85 \%$.

\section{Substrate used for the experiment}

The soil used for the experiment was collected from up to a depth of $0-15 \mathrm{~cm}$ at IITA-Benin. The soil is characterized as laterite with a $\mathrm{pH}$ of $5.20,30 \mathrm{~g}$ organic $\mathrm{C} \mathrm{kg}^{-}$ $1,2 \mathrm{~g} \mathrm{~K} \mathrm{Kg}^{-1}$ of soil. Total nitrogen and phosphorus were $5 \mathrm{~g} \mathrm{~N} \mathrm{~kg}^{-1}$ and $2.1 \mathrm{mg} \mathrm{P}$ $\mathrm{kg}^{-1}$, respectively. The soil was sieved through a $1 \mathrm{~mm}$ diameter mesh to remove stones and roots, autoclaved at $80 \pm 1^{\circ} \mathrm{C}$ for 3 days, and then air-dried. No fertilizer was applied during the experiment.

\section{Experiment design}

The experiment involved three factors: AMF (Funneliformis mosseae, Glomus dussii and non-inoculated control); yam cultivar (TDa98-165, TDa98-01183, TDr745, TDr97-00551); Meloidogyne spp. (500 infective juveniles $\left(\mathrm{J}_{2}\right)$ non-inoculated control). The experiment involved 24 treatments with 10 replications, giving in total 240 pots.

A single acclimatized tissue culture yam plants were planted in pots containing 1000 $\mathrm{cm}^{3}$ sterilized. For AMF treatments pots, 80 $\mathrm{g}$ of inoculum representing 500 spores, colonized roots and hyphal fragments from each inocula, were placed in a planting hole (1.5 cm diameter and $8 \mathrm{~cm}$ depth) made with a cylindrical stick, which was disinfected with $70 \%$ alcohol in between each pot.

Non-mycorrhizal controls received $80 \mathrm{~g}$ of autoclaved AMF inoculum. Funneliformis mosseae and $G$. dussii were commercial inocula obtained from BIORIZE ${ }^{\odot}$ (Dijon, France). The pots were maintained in the greenhouse over 7 months. 


\section{Meloidogyne spp. inoculum preparation and inoculation procedure}

Meloidogyne spp. were originally extracted from an infested yam tuber $(D$. rotundata, cv. laboko) collected from markets in Cotonou, Benin. The collected tubers were peeled, finely chopped and nematodes were extracted using a modified Baermann method (Coyne et al., 2007). The nematodes were maintained for 4 months in the greenhouse at IITA-Benin on tomato (cv. Pello) plants before removing, rinsing the roots which were finely chopped and macerated in $1.0 \% \mathrm{NaOCl}$ for $4 \mathrm{~min}$ to release eggs and $\mathrm{J} 2$ of Meloidogyne spp. Eggs and $\mathrm{J}_{2}$ were collected on a $20 \mu \mathrm{m}$ aperture sieve after passing through nested sieves, rinsing in five changes of tap water and then maintained in tap water for 10 days at room temperature. Hatched $\mathrm{J}_{2}$ were inoculated (two months after planting) into soil aside seedlings in a shallow trench of $\sim 5$ $\mathrm{cm}$ radius and $5-10 \mathrm{~cm}$ deep. The rate of Meloidogyne spp. inoculation was 500 $\mathrm{J}_{2} /$ plant in $10 \mathrm{ml}$ of water. Control plants received $10 \mathrm{ml}$ of tap water. All plants were subsequently watered with $300 \mathrm{ml}$ tap water per plant the day of panting and furthermore each two days. Prior to inoculation, the suspension was adjusted to $500 \mathrm{~J}_{2}$ per $10 \mathrm{ml}$ with tap water, by estimating from 3 replicates of $10 \mathrm{ml}$ aliquots using a Leica Wild M3C stereomicroscope and adjusting accordingly.

\section{Estimation of AMF root colonization}

Soil core samples were removed $24 \mathrm{~h}$ prior to harvest the yam tubers, according to Oehl et al. (2003) using two separate soil cores of a combined total of $30 \mathrm{~cm}^{3}$ (sampling depth $10 \mathrm{~cm}$ ) from each pot. Roots were extracted by wet sieving and decantation. Roots colonized by AMF were determined according to Brundrett et al. (1996), using trypan blue to stain the mycorrhizal structures. The gridline-intersect technique (Giovannetti and Mosse, 1980) was used to analyse AMF root colonization under a Leica Wild M3C at 90x magnification.

\section{Assessment of yam growth parameters}

At harvest (seven months after planting) the shoots were cut to soil level, tubers and roots were gently removed by hand. Shoots, roots and tubers from each pot were gently rinsed with tap water, air dried, labelled and stored in paper bags. Dry weight of shoots, roots and tubers were recorded following oven-drying in a well-ventilated Gallenkamp oven at $80^{\circ} \mathrm{C}$ for $72 \mathrm{~h}$ at IITA-Cotonou, Benin. Total dry root weights were calculated after taking into account material removed to determine mycorrhizal colonization and nematode density.

\section{Assessment of nematode density and} tuber galling symptoms

All tubers harvested were scored for galling severity on a scale of 1-5 (Claudius-Cole $e t$ al., 2005) where $1=$ clean tuber, $2=1-25 \%$ of tuber symptoms (low level of damage), 3 $=25-50 \%$ symptoms (low to moderate level of damage); $4=51-75 \%$ symptoms (moderate to severe level of damage); $5=$ $76-100 \%$ symptoms (high level of damage). All tubers were scored and the mean scores were calculated when more than one tuber per pot was present. Nematodes were extracted from the soil of each pot by mixing all the contents of each pot, removing a $100 \mathrm{ml}$ sub-sample and extracting using a modified Baermann plate method (Coyne et al., 2007). Meloidogyne spp. were also extracted from roots and tubers peels using the same technique after chopping into small pieces of 0.1 to $0.2 \mathrm{~cm}$ and removing $2 \times 5 \mathrm{~g}$ sub samples and macerating in $1.0 \% \mathrm{NaOCl}$ for $4 \mathrm{~min}$. Nematodes were counted with a Leica Wild M3C microscope 


\section{Data analysis}

All data were analysed using STATGRAPHICS, version 9.1 in Windows 2007. Three-Way ANOVA was used to compare yam growth parameters between treatments. Data on nematodes and on mycorrhization were analysed by one-way ANOVA. Prior to analysis, AMF spore density and nematode population were $\log _{10}$ $(\mathrm{x}+1)$ transformed, while data on mycorrhizal colonization were arcsin $(\mathrm{x} / 100)$ transformed in order to normalise data. Fischer's Least Significant Difference (LSD) Test was used to separate the means across treatments. Pearson's correlation was used to assess the association between root colonization and various growth parameters.

\section{Results and Discussion}

\section{Root colonization by AMF}

The AMF root colonization was significantly influenced by Meloidogyne spp. inoculation $(\mathrm{p}=0.028)$ and also appears as a function of AMF species and yam cultivar compatibility (Table 1). Moreover, the AMF root colonization was very low $(0.3 \%$ to $6 \%$ ) (figure1.a). Funneliformis mosseae inoculation resulted in higher root colonization for TDa98-01183 than G. dussii ( $\mathrm{p}=0.03$ ), while the root colonization was higher for Tdr cultivars with $G$. dussii than with $F$. mosseae ( $\mathrm{P}=0.03)$ (Figure 1.a).

\section{Effect of AMF and Meloidogyne spp. inoculation on yam plant growth}

Across cultivars, without Meloidogyne spp. inoculation, there was a significant interaction $(p=0.054)$ with AMF species for tubers dry weight. Inoculation with AMF led to higher tuber yields ( $p=0.001$, table 1 ; figure $1 \mathrm{~b}$ ), an observation consistent for Meloidogyne spp. inoculated plants $(p=$ 0.041 ; table 1$)$. Root dry weights were also significantly higher $(P=0.018$,$) with$ plantlets inoculated with $\mathrm{AMF}+$ Meloidogyne spp. compared to plantlets inoculated with Meloidogyne alone (figure 1d). Moreover, there were interactions between yam cultivars and Meloidogyne spp. inoculation $(p=0.0097)$ regarding shoot dry weight (Table 1). Shoot dry weight was significantly higher $(p=0.03)$ for TDa98-01183 when inoculated with $G$. dussii and Meloidogyne spp. compared to control (Figure $1 \mathrm{c}$ ).

Across yam cultivars, AMF root colonization was positively correlated with tuber weight $(\mathrm{p}=0.0006)$ and Meloidogyne spp. densities in soil $(\mathrm{p}=0.017)$ (Table 2). Positive correlations were observed between root colonization and tuber dry weight for TDa98-01183 ( $\mathrm{p}=0.04)$ and TDa98-165 (P $<0.001)$ and between root colonization and root dry weight for TDr745 ( $\mathrm{p}=0.028)$ while no correlation was observed between root colonization and tuber dry weight for TDa98-165 and TDr97-00551 (Table 2). Interesting, negative correlation was observed between root colonization and nematodes galls damages on root for all cultivars (Table 2)

Effect of AMF inoculation on Meloidogyne spp. density and yam tuber quality

At harvest, yam tuber galling was significantly lower $(\mathrm{p}=0.04)$ on plants inoculated with combined AMF species and Meloidogyne spp. than on plants having only Meloidogyne spp. inoculation (Table 1). Plantlets inoculated with Meloidogyne spp. had no roots at harvest and high galling damage of tubers, compared to plants inoculated with both AMF species and Meloidogyne spp. (Figure 2). For individual yam cultivars, only $F$. mosseae significantly suppressed Meloidogyne spp. tuber density on TDa98-165 ( $\leq$ 0.03) and Meloidogyne 
spp. root density on TDa98-01183 ( $\mathrm{p} \leq 0.01)$ (Table 3). Galling symptoms on tubers were statistically similar across treatments. Visually the application of AMF improved tuber quality of plants inoculated with Meloidogyne spp. (Figure 2).

The present study is the first known to assess the interaction and protective potential of AMF against Meloidogyne spp. on yam using in vitro plantlets. Usually, most plantlets at this stage would not be challenged or come in contact with nematodes, but for this study, it serves as an initial indicator on host reaction to AMF, the potential of AMF to protect against nematodes and the potential for using AMF as bio-enhancement of such planting material. The study also serves to help identify or assess suitable plant growth stages for inoculation, which will require further evaluation. It was suggested that the particular growth stage at which tissuecultured plantlets are inoculated with AMF is important but varies according to plant genotype (Smith and Read, 2008). The results showed clearly that there was relatively low root colonization by the AMF in the current study; while previously, the same combinations yielded up to $90 \%$ of root colonization (Tchabi, 2008). A possible explanation could relate to the difference of soil chemical properties. The substrate in the present study is more acid, with less extractable phosphorus than in Tchabi et al. (2016). Such differences in root colonization due to soil chemical composition were observed in Acer rubrum (Wiseman and Wells, 2005). Furthermore, the difference can be attributed to others abiotic factors, such as low availability of oxygen, which affected plant root colonization in salinized soil (Levy et al., 1983; Heikham et al., 2009).

Despite the low level of root colonization, the results of our study clearly show that there is a potential of AMF application on yam plantlets, in terms of improved production under non-pest challenged conditions. Without nematode challenge, our results demonstrated that application of commercially available AMF products can improve micro-tuber growth and development under glasshouse conditions, but that the degree of effectiveness is dependent on genotype or cultivar and on AMF strain/species. Previous studies have also noted this interaction between AMF and yam genotype under both greenhouse (Tchabi et al., 2010) and field conditions in Taiwan (Lu et al., 2015) and Nigeria (Oyetunji and Afolayan, 2007). In the current study AMF products commercially produced in Europe were used due to their availability, which may not be the most suitable or compatible for tropical conditions. Although the same products led to some high levels of yam root colonization in previous studies compared to populations locally isolated (Glomus etunicatum, G. hoi, G. clarium and Acaulospora scorbiculata) in Benin (Tchabi et al., 2010). Indeed survey studies in Benin and in Côte d'Ivoire showed that yam is highly mycorrhizal and associated with a wide diversity of AMF species (Tchabi et al, 2009; Nandjui et al., 2013).

Furthermore, studies have demonstrated that AMF positively influences plant growth in crops that are harvested for underground parts or tuber crops, such as cassava, potato, and sweet potato (Ekin et al., 2013; Hijri, 2016). It would appear therefore that yam is a suitable candidate for bio-enhancing with $\mathrm{AMF}$ and that by more precisely determining appropriate genotype $\mathrm{x}$ AMF strain combinations, suitable recommendations can be established, both for tissue culture micro-tuber conditions and for field conditions across climatic zones (Khosro et al., 2011; Berruti et al., 2016). 
Table.1 Analysis of variance table for yam cultivar, inoculation of Arbuscular mycorrhizal fungi and Meloidogyne spp. factor effects on micropropagated yam plantlet growth, AMF development and nematode parameters

\begin{tabular}{|c|c|c|c|c|c|c|c|}
\hline \multirow[t]{2}{*}{ Variable } & \multicolumn{7}{|c|}{ Factors } \\
\hline & $\begin{array}{l}\text { Cultivar } \\
\text { (A) }\end{array}$ & $\begin{array}{l}\mathrm{AMF}^{1} \\
(\mathrm{~B})\end{array}$ & $\begin{array}{l}\text { Meloidogyne } \\
\text { spp. }^{2} \text { (C) }\end{array}$ & $\mathrm{AxB}$ & $\mathrm{AxC}$ & $\mathrm{BxC}$ & $\mathrm{AxBxC}$ \\
\hline \multicolumn{8}{|c|}{ Colonization } \\
\hline Df & 3 & 2 & 1 & 6 & 3 & 2 & 6 \\
\hline $\mathbf{F}$ & 0.25 & 4.02 & 100.21 & 5.88 & 34.8 & 42.36 & 18.41 \\
\hline $\mathrm{p}$ & 0.86 & 0.02 & 0.028 & 0.94 & 0.69 & 0.130 & 0.496 \\
\hline \multicolumn{8}{|l|}{ TDW } \\
\hline Df & 3 & 2 & 1 & 6 & 3 & 2 & 6 \\
\hline $\mathrm{F}$ & 2.28 & 6.87 & 4.29 & 2.18 & 1.06 & 0.08 & 0.68 \\
\hline $\mathrm{p}$ & 0.086 & 0.001 & 0.041 & 0.054 & 0.36 & 0.92 & 0.66 \\
\hline \multicolumn{8}{|l|}{ SDW } \\
\hline Df & 3 & 2 & 1 & 6 & 3 & 2 & 6 \\
\hline $\mathrm{F}$ & 3.21 & 0.71 & 2.03 & 1.93 & 4.06 & 1.21 & 0.19 \\
\hline $\mathrm{p}$ & 0.027 & 0.49 & 0.15 & 0.086 & 0.0097 & 0.30 & 0.97 \\
\hline \multicolumn{8}{|l|}{ RDW } \\
\hline Df & 3 & 2 & 1 & 6 & 3 & 2 & 6 \\
\hline $\boldsymbol{F}$ & 1.63 & 1.09 & 5.87 & 0.57 & 0.11 & 0.01 & 0.42 \\
\hline $\mathrm{p}$ & 0.18 & 0.34 & 0.018 & 0.75 & 0.95 & 0.99 & 0.86 \\
\hline \multicolumn{8}{|c|}{ Galling score } \\
\hline$D f$ & 3 & 2 & 1 & 6 & 3 & 2 & 6 \\
\hline $\mathrm{F}$ & 3.28 & 3.20 & 259.6 & 0.97 & 1.21 & 4.15 & 0.96 \\
\hline $\mathrm{p}$ & 0.025 & 0.046 & 0.0001 & 0.45 & 0.309 & 0.019 & 0.460 \\
\hline \multicolumn{8}{|c|}{ Density $\mathbf{J}_{2}$ root } \\
\hline Df & 3 & 2 & 1 & 6 & 3 & 2 & 6 \\
\hline $\mathrm{F}$ & 1.38 & 1.00 & 12.62 & 1.10 & 1.38 & 1.00 & 1.10 \\
\hline $\mathrm{p}$ & 0.25 & 0.37 & 0.001 & 0.36 & 0.25 & 0.37 & 0.36 \\
\hline \multicolumn{8}{|c|}{ Density $\mathbf{J}_{2}$ soil } \\
\hline Df & 3 & 2 & 1 & 6 & 3 & 2 & 6 \\
\hline$F$ & 0.83 & 1.36 & 18.15 & 0.95 & 0.83 & 1.36 & 0.95 \\
\hline$p$ & 0.21 & 0.25 & 0.001 & 0.46 & 0.48 & 0.25 & 0.46 \\
\hline \multicolumn{8}{|c|}{ Density $\mathrm{J}_{2}$ tuber } \\
\hline Df & 3 & 2 & 1 & 6 & 3 & 2 & 6 \\
\hline $\mathrm{F}$ & 0.83 & 1.36 & 18.15 & 0.95 & 0.83 & 1.36 & 0.95 \\
\hline $\mathrm{p}$ & 0.21 & 0.25 & 0.001 & 0.46 & 0.48 & 0.25 & 0.46 \\
\hline
\end{tabular}

Tuber galling severity were assessed on a scale from 1 to 5 (Claudius-Cole et al., 2005) where $1=$ clean tuber; $2=$ $1-25 \%$ tuber galling symptoms (low level of damage); $3=25-50 \% ; 4=51-75 \% ; 5=76-100 \%$.

${ }^{1} \mathrm{AMF}$ inoculated at rate of 300 spores per pot at yam plantlet transplanting into individual pot.

${ }^{2}$ Meloidogyne spp. inoculated at a rate of $500 \mathrm{~J}_{2}$ (juveniles) two months after AMF inoculation. TDW = tuber dry weight; SDW = shoot dry weight; RDW = root dry weight. 
Table.2 Pearson correlation analysis between Arbuscular mycorrhizal fungal root colonization and yam plant growth parameters (tuber number, tuber fresh weight) or nematode damage scores (galling) and $\mathrm{J} 2$ density.

\begin{tabular}{llllll}
\hline Cultivars & & TDW & RDW & Galling & J2 density \\
\hline All cultivars & r value & 0.32024 & 0.00019 & -0.0144 & 0.03015 \\
& P value & 0.006 & 0.99 & 0.04 & 0.6421 \\
TDa98-165 & r value & 0.36800 & 0.12556 & -0.2746 & -0.0746 \\
& P value & $<0.001$ & 0.33 & 0.03 & 0.5709 \\
TDa98-01183 & r value & 0.39071 & 0.21152 & -0.10099 & 0.16321 \\
& P value & 0.0484 & 0.10 & 0.044 & 0.2128 \\
TDr 745 & r value & 0.31367 & 0.42968 & -0.0878 & -0.0154 \\
& P value & 0.19 & 0.0285 & 0.050 & 0.90 \\
TDr87-00551 & r value & 0.17042 & 0.11005 & 0.07170 & 0.06486 \\
& P value & 0.019 & 0.40 & 0.05862 & 0.62 \\
\hline
\end{tabular}

Fig 1 Percentage root colonization (a) and effect of Arbuscular mycorrhizal fungal Funneliformis mosseae and G. dussii) and Meloidogyne spp. inoculation on micropropagated yam plantlet growth(b, c and d) of four yam cultivars (TDr745, TDr97-00551,TDa98-165, TDa98-01183) in pots under greenhouse conditions. Values are means ( $\square$ SE) of ten replicates at harvest, seven and five months after AMF and Meloidogyne spp. inoculation, respectively.

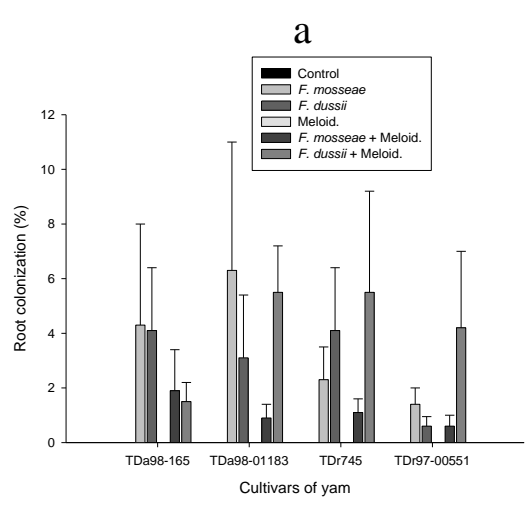

C

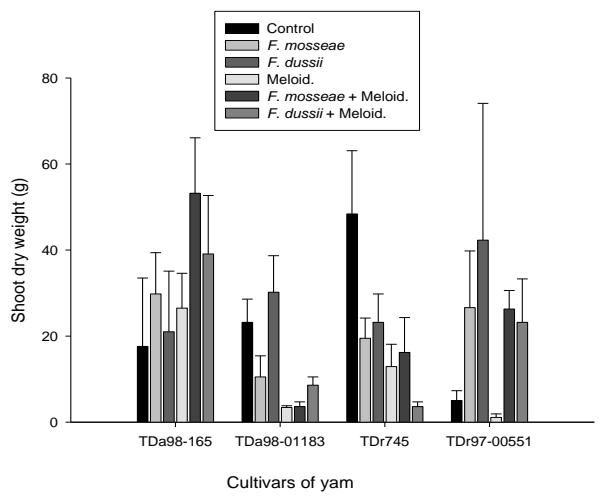

b
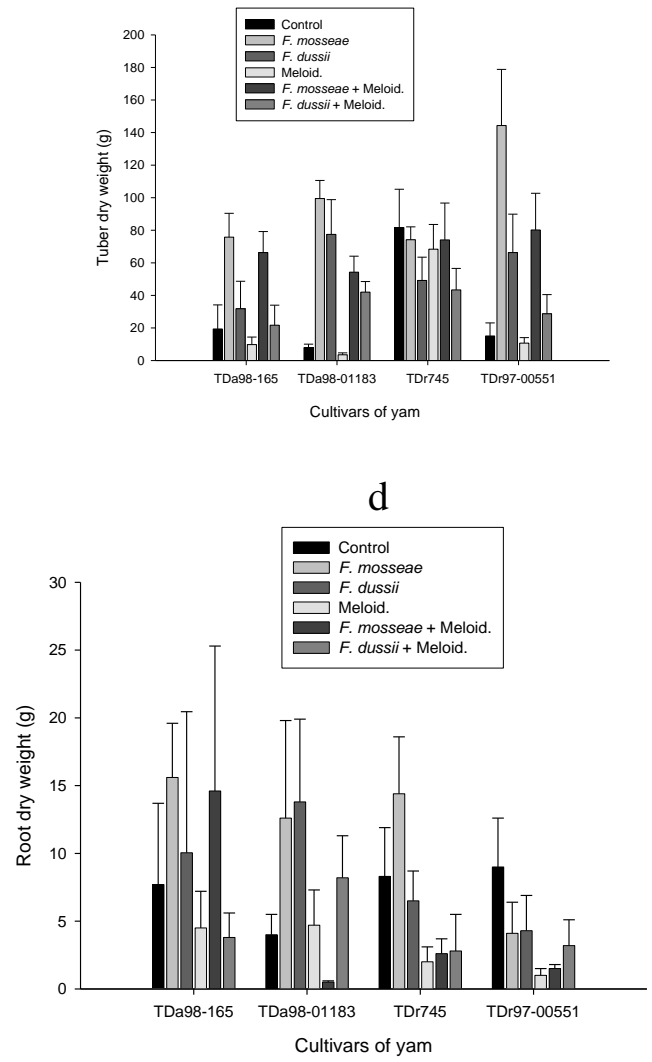
Table.3 Tuber galling and the mean population density of Meloidogyne spp. at harvest seven and five months after Arbuscular mycorrhizal fungi (F. mosseae and G. dussii) and Meloidogyne spp. inoculation, respectively, to yam micropropagated plantlets of two cultivars of Dioscorea rotundata (TDr745, TDr97-00551) and two cultivars of D. alata (TDa98-165; TDa98-01183) under screen house conditions

\begin{tabular}{|c|c|c|c|c|c|c|c|c|}
\hline \multirow[t]{2}{*}{ Treatments } & \multicolumn{2}{|c|}{ Tubers galling } & \multicolumn{2}{|c|}{$\begin{array}{c}\text { Meloidogyne spp. density }^{1} \\
\text { (root) }\end{array}$} & \multicolumn{2}{|c|}{$\begin{array}{c}\text { Meloidogyne spp. density }{ }^{2} \\
\text { (soil) }\end{array}$} & \multicolumn{2}{|c|}{$\begin{array}{l}\text { Meloidogyne spp } \\
\text { Density }^{3} \text { (tuber) }\end{array}$} \\
\hline & non-inoc & inoc & $\begin{array}{l}\text { non- } \\
\text { inoc }\end{array}$ & -inoc & non-inoc & inoc & $\begin{array}{l}\text { non- } \\
\text { inoc }\end{array}$ & inoc \\
\hline \multicolumn{9}{|l|}{ TDa98-165 } \\
\hline Control & $0.8 \pm 0.2$ & $5 \pm 0.3 \mathrm{a}$ & - & $2977.6 \pm 1615.3$ & - & $734.2 \pm 356.9$ & - & $77 \pm 0.2 b$ \\
\hline G. mosseae & $1 \pm 0.0$ & $3 \pm 0.6 \mathrm{~b}$ & - & $1687.3 \pm 716.7$ & - & $148.3 \pm 55.9$ & - & $56 \pm 0.6 a$ \\
\hline G. dussii & $0.8 \pm 0.4$ & $3.2 \pm 0.4 b$ & - & $236.4 \pm 167.5$ & - & $202.5 \pm 138.1$ & - & $63 \pm 0.3 b$ \\
\hline $\mathrm{p}$-value & 0.67 & 0.02 & & 0.20 & & 0.15 & & 0.03 \\
\hline \multicolumn{9}{|l|}{ TDa98-01183 } \\
\hline Control & $1.0 \pm 0.0$ & $4.8 \pm 09$ & - & $560.8 \pm 324.9 \mathrm{a}$ & - & $727.3 \pm 655.8$ & - & $85 \pm 0.3$ \\
\hline G. mosseae & $1.0 \pm 0.0$ & $3.0 \pm 1.3$ & - & $457.5 \pm 354.1 \mathrm{a}$ & - & $1055.6 \pm 724.5$ & - & $69 \pm 0.4$ \\
\hline G. dussii & $1.0 \pm 0.1$ & $3.3 \pm 0.5$ & - & $135.2 \pm 85.5 b$ & - & $354.3 \pm 117.9$ & - & $71 \pm 0.6$ \\
\hline $\mathrm{p}$-value & 0.9 & 0.03 & & 0.01 & & 0.12 & & 0.48 \\
\hline \multicolumn{9}{|l|}{ TDr745 } \\
\hline Control & $1.0 \pm 0.1$ & $4.7 \pm 0.6$ & - & $1308.3 \pm 530.5$ & - & $1048.3 \pm 581.8$ & - & $102 \pm 0.2$ \\
\hline G. mosseae & $1.0 \pm 0.0$ & $3.6 \pm 0.2$ & - & $178.3 \pm 110.3$ & - & $85.8 \pm 44.6$ & - & $59 \pm 0.0$ \\
\hline G. dussii & $1.0 \pm 0.2$ & $3.7 \pm 0.1$ & - & $110.2 \pm 39.6$ & - & $155.5 \pm 82.3$ & - & $58 \pm 0.2$ \\
\hline $\mathrm{p}$-value & 0.81 & 0.05 & & 0.3 & & 0.26 & & 0.71 \\
\hline \multicolumn{9}{|l|}{ TDr97-00551 } \\
\hline Control & $1.0 \pm 0.0$ & $4.0 \pm 0.3$ & - & $53.3 \pm 13.2$ & - & $225.6 \pm 142.4$ & - & $156 \pm 0.1$ \\
\hline G. mosseae & $1.0 \pm 0.1$ & $2.3 \pm 0.6$ & - & $2720.3 \pm 1516.3$ & - & $125.3 \pm 72.7$ & - & $73 \pm 0.1$ \\
\hline G. dussii & $0.7 \pm 0.3$ & $3.5 \pm 0.3$ & - & $2053.3 \pm 1309.5$ & - & $460.8 \pm 170.8$ & - & $63 \pm 0.2$ \\
\hline p-value & 0.6 & 0.04 & - & 0.51 & - & 0.23 & - & 0.39 \\
\hline
\end{tabular}

Roots and soil from non-inoculated treatments were nematode free. - = no data collected. Analysis and means separation of nematode densities were undertaken on $\log _{10}(\mathrm{x}+1)$ transformed data. ${ }^{1}$ Nematode density per $5 \mathrm{~g}$ of root; ${ }^{2}$ Nematode density per $50 \mathrm{~g}$ soil. ${ }^{3}$ Values were mean $( \pm$ SE) of six replicates non transformed data. For each yam cultivar means were compared by columns. Means followed by the same letter were not significant difference $(P>0.05)$ according to the Protected Least Significant Different Test (LSD). Inoc = inoculated and non-inoc = non-inoculated with Meloidogine spp. Tuber galling severity were assessed on a scale from 1 to 5 (Claudius-Cole et al., 2005) where $1=$ clean tuber; $2=1-25 \%$ tuber galling (low level of damage); $3=25-50 \% ; 4=51-75 \% ; 5=76-$ $100 \%$. 
Fig.2 Yam tubers and roots at harvest seven months after planting following Arbuscular mycorrhizal fungi inoculation at planting and Meloidogyne spp. inoculation two months after planting.

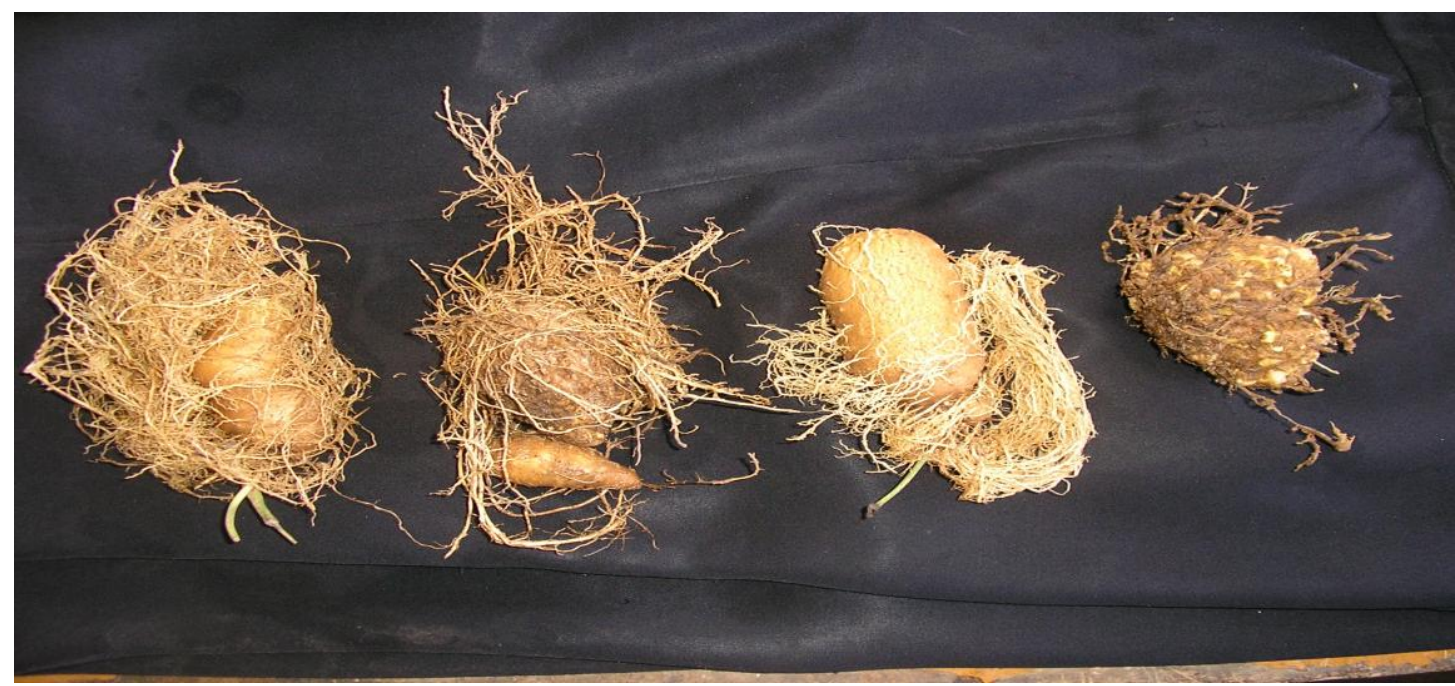

Legend: $\mathrm{A}=$ Control, $\mathrm{B}=F$. mosseae + Meloidogyne spp., $\mathrm{C}=$ F. mosseae, $\mathrm{D}=$ Meloidogyne spp.

Regarding suppression of nematodes and nematode damage by AMF and the current study provided further confirmation of the positive impact of AMF on such biotic challenges. Again, the interaction between yam genotype and AMF affected the response, with the cv. TDa98-01183 responding more efficiently in terms of tuber yield to inoculation with $F$. mosseae and Meloidogyne spp., compared to Meloidogyne spp. alone. This result also compares favourably with earlier studies assessing the impact of AMF on the yam nematode Scutellonema bradys (Tchabi et al., 2016). The current study, however, indicates that AMF inoculation enables yam plantlets to recover from Meloidogyne spp. injuries, possibly through the pcompensation phenomena (Harrier and Watson, 2004; Schouteden et al., 2015). Although the AMF had no influence on nematode densities, galling damage symptoms were lower in the presence of AMF and tubers visibly healthier (cleaner) and of better quality (Fig 2). It has been shown that the intensity of colonization by AMF can be a determining factor on the response of mycorrhized plants to nematode parasitism (Smith et al., 1986). Meloidogyne hapla for example, was absent in cortical tissues of alfalfa roots when over $10 \%$ of roots were colonized (Grandison and Cooper, 1986), while in cotton, $M$. incognita was inhibited only when roots were $50 \%$ colonized by Glomus intraradices (Smith et al., 1986).

In our study, the $6 \%$ yam root colonization by $F$. mosseae and $G$. dussii was likely insufficient to suppress the development of Meloidogyne spp. on the host root. These results reflect those of Ryan et al. (2003), who reported that with less than $50 \%$ of root colonization, the population of potato cyst nematodes (Globodera rostochiensis and $G$. pallida) was not suppressed on potato plants inoculated with the commercial product Vaminoc $^{\circledR}$ (combination of three Glomus spp.). However, our results were contradictory to former reports, which 
established the suppression (roots and soil) of $M$. incognita in tomato (Grandison and Cooper, 1986; Talavera et al., 2001), M. hapla on onion (MacGuidwin et al., 1985) and on banana (Jaizme-Vega et al., 1997) with low root colonization. The difference between our results and those former studies on AMF suppressing Meloidogyne spp. population densities may be explained by the fact that a single species of Meloidogyne spp. in more often used in these inoculation studies, while in the present study, the inoculum of the Meloidoygyne spp. included a mixture of two species (M. incognita and Meloidogyne spp).

The reduction in number of galls, observed on roots of yam plantlets could be due to the competition between the pathogen and the symbiont for infection sites, but other factors such as increase of lignin and phenols (Umesh et al., 1988) or nematicide substances, such as phenylalanine and serine (Suresh et al., 1985) can be involved. Our present results reflect those of Kellam and Schenck (1980) who registered lower quantity of galls in mycorrhizal soybean plants than in non-mycorrhizal.

In conclusion, the current study provides further supporting evidence on the use of AMF for the protection of crops against nematode pests. It also supports the use of bio-enhancing tissue culture plantlets for improving their growth and production, in this case yam micro-tubers. However, AMF species influence on plant growth appears highly dependent on the plant genotype with which they are associated. Taking into consideration tuber weight, AMF attributes and nematode management, the product based on $F$. mosseae was more effective than the $G$. dussii-based product at improving growth and reducing nematode damage. Although, prior to further application of the present result in the field, a broader assessment should be recommended for selecting the best combination AMF strain/species $\mathrm{x}$ yam genotype. Assessment of available commercial products enables a relatively rapid ability to determine the suitability of products that are currently accessible, while assessment of local indigenous population provides a longer term strategy for development of products based around populations that may be more acclimatized to local conditions.

\section{Acknowledgement}

The work was supported by grants from the Swiss Center for International Agriculture (ZIL: http://www.rfpp.ethz.ch), the IndoSwiss Collaboration in Biotechnology (ISCB: http://iscb. epfl.ch/), and the Swiss National Science Foundation.

\section{References}

Adegbite, A.A., Adesiyan, S.O., Adbaje, G.O. and Omoloye, A.A. 2005. Host suitability of crops under yam intercrop to root-knot nematode ( $M$. incognita Race 2) in South-Western Nigeria. $J$. Agr. Rural Dev. Trop., 106: 113-118.

Adesiyan, S.O. and Adeniji, M.O. 1976. Studies on some aspect of yam nematode management (Scutellonema bradys). Ghana J. Agric. Sci., 4: 21-32.

Affokpon, A., Coyne, D.L., Lawouin, L., Tossou, C., Agbède, R.D., Coosemans, J. 2011. Effectiveness of native West African arbuscular mycorrhizal fungi in protecting vegetable crops against rootknot nematode. Biol. Fertil. Soils, 47: 207-217.

Agu, C.M. 2008. Effects of organic manure types on root-gall nematode disease and african yam bean Yield. J. Am. Sci., 4: 1545-1003.

Ayensu, E.S. and Coursey, D.G. 1972. Guinea yams: the botany, ethnobotany, use and 
possible future of yams in West Africa. Econ. Bot., 26: 301-318.

Ayodele, A.A. and Agbaje, G.O. 2007. Efficacy of furadan (carbofuran) in control of root-knot nematode (Meloidogyne incognita race2) in hybrid yam varieties in south-western Nigeria. Appl. Soil Ecol., 45: 92-100.

Azcón-Aguilar, C. and Barea, J.M. 1997. Arbuscular mycorrhizas and biological control of soil-borne plant pathogens an overview of the mechanisms involved. Mycorrhiza, 6: 457-464.

Berruti, A., Lumini, E., Balestrini, R. and Bianciotto, V. 2016. Arbuscular Mycorrhizal Fungi as Natural Biofertilizers: Let's Benefit from Past Successes, Review. Front. Microbiol., 6: article1559.

Borowicz, V.A. 2001. Do arbuscular mycorrhizal fungi alter plant-pathogen relations?. Ecol., 82: 3057-3068.

Bridge, J., Coyne, D.L. and Kwoseh, C.K. 2005. Nematode parasites on Root and Tuber Crop. In: Luc, M., Sikora, R.A. and Bridge, J. (eds), Plant Parasitic Nematodes in Subtropical and Tropical Agriculture, 2nd Edition, CAB International. Wallingford, UK. pp 221258.

Brundrett, M.C., Melville L. and Peterson, M.C. 1994. Practical methods in mycorrhizal research. Mycologue Publications: Ontario.

Carpio, L.A., Davies, F.T. and Arnold, M.A. 2005. Arbuscular mycorrhizal fungi, organic and inorganic controlled-release fertilizers: Effect on growth and leachate of container-grown bush morning glory (Ipomoea carnea ssp. fistulosa) under high production temperatures. J. Am. Soc. Hortic. Sci., 130: $131-139$

Cassells, A.C. 2012. Pathogen and biological contamination management in plant tissue culture: phytopathogens, vitro pathogens, and vitro pests". Methods Mol. Biol., 877: 57-80.

Claudius-Cole, A.O. 2005. Cover crops in the management of Meloidogyne spp. and Scutellonema bradys on edible yam, studies in Nigeria. Ph.D Thesis Faculty of Agriculture University of Ibadan, Ibadan. Nigeria.

Claudius-Cole, A.O., Fawole, B., Asiedu, R. and Coyne, D.L. 2014. Management of Meloidogyne incognita in yam-based cropping systems with cover crops. Crop Prot., 63: 97-102.

Coyne, D.L., Claudius-Cole A.O., Kenyonand, L. and Baimey, H. 2009. Differential effect of hot water treatment on whole tubers versus cut setts of yam (Dioscorea spp.). Pest Manag. Sci., 66: 385-38.

Coyne, D.L., Nicol J. and Claudius-Cole, A. 2007. Practical Plant Nematology: Field and Laboratoty Guide". IITA, Ibadan, Nigeria. pp. 82.

Coyne, D.L., Tchabi, A., Baimey, H., Labuschagne, N. and Rotifa I. 2006. Distribution and prevalence of nematodes (Scutellonema bradys and Meloidogyne spp. on marketed yam (Dioscorea spp.) in West Africa. Field Crops Res., 96: 142-150.

Ekin, Z., Demir, S., Oguz, F. and Yildirim, B. 2013. Effect of Arbuscular Mycorrhizal Fungus (AMF) Glomus intraradices with different potassium fertilizer levels on the tuber yield and size distribution of potato (Solanum tuberosum L.). J. Agr. Sci., 23: 154-163.

Ettien, D.J.B., F. Sorho and Koné, B. 2013. Screening of new yam clones $(D$. alata and $D$. rotundata) in nematode prone ecology of guinea savanna zone in West Africa. J. Appl. Biosci., 61: 4540-4550.

Farmer, M.J., Li, X., Feng, G., Zhao, B., Chatagnier, O., Gianinazzi, S., Gianinazzi-Pearson, V. and van Tuinen, D. 2006. Molecular monitoring of fieldinoculated arbuscular mycorrhizal fungi to evaluate persistence in sweet potato crops in China. Appl. Soil Ecol., 35: 599-609.

Food and Agriculture Organisation of the United Nations (FAO) 2013. Statistics 
Division. Available at: http://faostat3.fao.org/download/Q/QC/ E.

Giovannetti, M. and Mosse, B. 1980. An evaluation of techniques for measuring vesicular arbuscular mycorrhizal infection in roots. New Phytol., 84: 489500 .

Grandison, G.S. and Cooper, K.M. 1986. Interaction of vesicular-arbuscular mycorrhizae and cultivars of alfalfa susceptible and resistant to Meloidogyne hapla.. J. Nematol., 18: 141-149.

Halder, M., Mujib, A.S.M., Khan, M.S., Joardar, J.C., Akhter, S. and Dhar, P.P. 2015. Effect of Arbuscular Mycorrhiza Fungi Inoculation on Growth and Up take of Mineral Nutrition in Ipomoea Aquatica. Curr. World Environ., 10: 6775.

Harrier, L.A. and Waston, C.A. 2004. The potential role of arbuscular mycorrhizal (AM) fungi in the bioprotection of plants against soil-borne pathogens in organic and/or other sustainable farming systems. Pest Manage. Sci., 60: 149157.

Heikham, E., Kapoor, R. and Bhoopander, G. . 2009. Arbuscular mycorrhizal fungi in alleviation of salt stress: a review. Ann. Bot., 104: 1263-1280.

Hijri, M. 2016. Analysis of a large dataset of mycorrhiza inoculation field trials on potato shows highly significant increases in yield. Mycorrhiza, 26: 209214.

Hol, W.H.G. and Cook, R. 2005. An overview of arbuscular mycorrhizal funginematode interactions. Basic Appl. Ecol., 6: 489-503.

International Institute of Tropical Agriculture (IITA) "Annual Report", Ibadan, Nigeria, 2006.

International Institute of Tropical Agriculture (IITA), “Annual Report”. Ibadan, Nigeria, 2014.

Jaizme-Vega, M.C., Tenoury P., Pinochet. J., Jaumot, M. 1997. Interactions between the root-knot nematode Meloidogyne incognita and Glomus mosseae in banana. Plant Soil, 196: 27-35.

Kellam, M.K. and Schenck, N.C. 1980. Interactions between a vesiculararbuscular mycorrhizal fungi and rootknot nematode on soybean. Phytopathol., 70: 293-296.

Khosro, M. Shiva K., Sohrabi, Y., Gholamreza, H. 2011. A Review: Beneficial Effects of the Mycorrhizal Fungi for Plant Growth. J. Appl. Environ. Biol. Sci., 1: 310-319.

Kolombia, Y.A., Karssen, G., Viaene, N., Kumar, P.L., Coyne D.L. and Bert, W. 2014. Identification and diversity of the root-knot nematodes affecting yam (Dioscorea spp.) in Nigeria. $J$. Nematol., 46: 190-190. 6th International Congress of Nematology, South Africa.

Levy, Y., Dodd, J. and Krikun, J. 1983. Effect of irrigation water salinity and rootstock on the vertical distribution of vesiculararbuscular mycorrhiza in citrus roots. New Phytol., 95: 397-403.

Lone, R., Shuab, R. and Koul, K.K. 2016. AMF Association and Their Effect on Metabolite Mobilization, Mineral Nutrition and Nitrogen Assimilating Enzymes in Saffron (Crocus sativus) Plant. J. Plant Nutr., 0: 00-00.

Lu, F.C., Lee, C.Y. and Wang, C.L. 2015. The influence of arbuscular mycorrhizal fungi inoculation on yam (Dioscorea spp.) tuber weights and secondary metabolite content. Peer J., 3: e1266.

MacGuidwin, A.E., Bird G.W., Safir, G.R. 1985. Influence of Glomus fasciculatum on Meloidogyne hapla infecting Allium cepa. J. Nematol., 17: 389-395.

McSorley, R. 2011. Overview of Organic Amendement for Management of PlantParasitic Nematodes, with Case Studies from Florida. J. Nematol., 43: 69-81.

Naher, U.A., Othman R. and Panhwar, Q.A. 2013. Beneficial effects of mycorrhizal association for crop production in the tropics -a review. Int. J. Agr. Biol., 1: 1021-1028. 
Nandjui, J., Voko, D.R.R., .Kouadio, A.N.M.S, Fotso, B. , Tano, Y. and Zeze, A. 2013. Assessment of the occurrence and abundance of mycorrhizal fungal communities in soils from yam (Dioscorea spp.) cropping fields in Dabakala, North Côte d'Ivoire. Afr. J. Agric. Res., 8: 5572-5584.

Nwauzor, E.C. and Fawole, B. 1981. Root knot nematodes on yams in eastern Nigeria. Proceedings of the Third Research Planning Conference on Rootknot nematode damage to yam in field and storage. International Institute of Tropical Agriculture (IITA), Ibadan, Nigeria.

Oehl, F., Sieverding, E., Ineichen, K., Mäder, P., Boller, T. and Wiemken, A., 2003. Impact of land use intensity on the species diversity of arbuscular mycorrhizal fungi in agroecosystems of Central Europe. Appl. Environ. Microbiol., 69: 2816-2824.

Onyeke, C.C. and Akueshi, C.O. 2012. Pathogenicity and reproduction of Meloidogyne incognita (Kofoid and White) chitwood on African yam bean, Sphenostylis stenocarpa (Hochst Ex. A. Rich) Harms accessions, Afr. J. Biotechnol., 11: 1607-1616.

Orkwor, G.C. 1998. The importance of yam. In: Orkwor, G.C., Asiedu, R. and Ekanayake, I.J. (eds) "Food Yams": Advances in Research, IITA and NRCRI, Nigeria pp.1-12.

Osei, K., Danso, Y., Otoo E., Adomako J., Sackey-Asante J. and Abugri, B. 2015. Evaluation of yam varieties for reaction to plant parasitic nematodes infestation in three agro-ecologies of Ghana. Int. J. Agr. Sci. Res., 3: 201-206.

Osei, K., Otoo, E. Danso, Y. Adomako, J. Agyeman, A., Asante, J.S. 2013. Organic soil amendements in nematode management in yam production. Nematropica, 43: 78-82.

Oyetunji, O.J. and Afolayan, E.T. 2007. The relationship between relative water content, chlorophyll synthesis and yield performance of yam (Dioscorea rotundata) as affected by soil amendments and mycorrhizal inoculation. Arch. Agron. Soil Sci., 53: 335-344.

Ryan, M.H. and Angus, J.H. 2003. Arbuscular mycorrhizal fungi in wheat and field pea crops on a low $\mathrm{P}$ soil: increased $\mathrm{Zn}$ uptake but no increase in P-uptake or yield. Plant Soil, 250: 225-239.

Sanchez, P.A. 2002. Soil fertility and hunger in Africa. Sci., 295: 2019-2020.

Schouteden, N., De Wale, D., Panis, B. and Vos, M.C. 2015. Arbuscular Mycorrhizal Fungi for the Biocontrol of Plant-Parasitic Nematodes: A Review of the Mechanisms Involved. Front. Microbiol., 6: article 1280.

Smith S E and Read D J, Mycorrhizal Symbiosis, $3^{\text {rd }}$ edn. Academic Press, London, UK, 2008.

Smith, G.S., Hussey, R.S. and Roncadori, R.W. 1986. Penetration and postinfection development of Meloidogyne incognita on cotton as affected by Glomus intraradices and phosphorus. $J$. Nematol., 18: 429-435.

Speijer, P.R. 1996. Hot water treatment: a possible strategy for farmer group and NGOs. In: Green, K.R. and Florini, D.A. (eds) Pests and pathogens of yams in storage: a workshop report. Afr. J. Root Tuber Crops, 1: 38-42.

StatPoint, Inc. 2007. The Multilingual Statgraphics Centurion User's Guide, Statistics.

Straker, C.J., Hilditch A.J., Rey, M.E.C. 2010. Arbuscular mycorrhizal fungi associated with cassava (Manihot esculenta Crantz). S. Afr. J. Bot., 76: 102-111.

Suresh, C.K., Bagyaraj D.J. and Reddy, D.D.R. 1985. Effect of vesiculararbuscular mycorrhiza on survival, penetration and development of rootknot nematode in tomato. Plant and Soil, 87: 305-308.

Talavera, M., Itou, K., Mizukubo, T. 2001. Reduction of nematode damage by root colonization with arbuscular mycorrhiza 
(Glomus spp.) in tomato-Meloidogyne incognita (Tylenchida: Meloidogynidae) and carrot-Pratylenchus penetrans (Tylenchida: Pratylenchidae) pathosystems. Appl. Entomol. Zool., 36: 387-392.

Tchabi, A. 2008. Arbuscular Mycorrhizal Fungi in the Sub-Saharan Savannas of Benin and their Association with Yam (Dioscorea spp.): Potential of Yam Growth Promotion and Reduction of Nematode Infestation. Ph.D Thesis. Institute of Botany, University of Basel, Switzerland.

Tchabi, A., Burger, S., Coyne D.L., Hountondji F., Lawouin L., Wiemken A. and Oehl, F. 2009. Promiscuous arbuscular mycorrhizal symbiosis of yam (Dioscorea spp.), a key staple crop in West Africa. Mycorrhiza, 19: 375392.

Tchabi, A., Coyne D.L., Hountondji, F., Lawouin L., Wiemken A. and Oehl, F. 2010. Efficacy of indigenous arbuscular mycorrhizal fungi for promoting white yam (Dioscorea rotundata) growth in West Africa. Appl. Soil. Ecol., 45: 92100.
Tchabi, A., Hountondji F.C.C., Ogunsola B., Lawouin L., Coyne D.L., Wiemken, A and Oehl, F. 2016. Effect of two species of arbuscular mycorrhizal fungi inoculation on development of micropropagated yam plantlets and suppression of Scutellonema bradys (Tylenchideae). J. Entomol. Nematol., 8: 1-10.

Umesh, K.C., Krishnappa K. and Bagyaraj, D.J. 1988. Interaction of burrowing nematode, Radopholus similis (Cobb, 1983) Thorne 1949, and VA mycorrhiza, Glomus fasciculatum (Thaxt) Gerd and Trappe, in banana (Musa acuminata Colla). Indian $J$. Nematol., 18: 6-11.

Wiseman, P.E. and. Wells, C.C. 2005. Soil inoculum potential and arbuscular mycorrhizal colonization of Acer rubrum in forested and developed landscapes. J. Arboric., 31: 296-302.

Wu, F., Wang, W., Ma, Y., Liu, Y., Ma, X., An, L. and Feng, H. 2013. Prospect of beneficial microorganisms applied in potato cultivation for sustainable agriculture". Afr. J. Microbiol. Res., 7: 2150-2158.

\section{How to cite this article:}

Atti Tchabi, Fabien C.C. Hountondji, Bisola Ogunsola, Louis Lawouin, Danny Coyne, Andres Wiemken and Fritz Oehl. 2016. The Influence of Arbuscular Mycorrhizal Fungi Inoculation on Micro-Propagated Hybrid Yam (Dioscorea spp.) Growth and Root Knot Nematode (Meloidogyne spp.) Suppression. Int.J.Curr.Microbiol.App.Sci. 5(10): 267-281. doi: http://dx.doi.org/10.20546/ijcmas.2016.510.030 